\title{
Blending effect of Campbell Early and aronia wines fermented by the mixed culture of Pichia anomala JK04 and Saccharomyces cerevisiae Fermivin
}

\author{
Hyo-sung Jeong $^{1}$, Sae-Byuk Lee ${ }^{1}$, Su-bin Yeo ${ }^{1}$, Da-Hye Kim ${ }^{1}$, Jun-Su Choi ${ }^{1}$, \\ Dong-Hwan Kim ${ }^{1}$, Soo-Hwan Yeo ${ }^{2}$, Heui-Dong Park ${ }^{1,3 *}$ \\ ${ }^{1}$ School of Food Science and Biotechnology, Kyungpook National University, Daegu 40566, Korea \\ ${ }^{2}$ Fermented Food Science Division, Department of Agro-Food Resources, NIAS, RDA, Wanju 55365, Korea \\ ${ }^{3}$ Institute of Fermentation Biotechnology, Kyungpook National University, Daegu 40566, Korea
}

\section{Pichia anomala JK04와 Saccharomyces cerevisiae Fermivin 혼합발효에 의한 캠벨얼리 와인과 아로니아 와인의 블렌딩 효과}

\author{
정효성 ${ }^{1} \cdot$ 이새벽 ${ }^{1} \cdot$ 여수빈 $^{1} \cdot$ 김다혜 $^{1} \cdot$ 최준수 $^{1} \cdot$ 김동환 $^{1} \cdot$ 여수환 $^{2} \cdot$ 박희동 $^{1,3 *}$ \\ ${ }^{1}$ 경북대학교 식품공학부, ${ }^{2}$ 농촌진흥청 국립농업과학원 농식품자원부, ${ }^{3}$ 경북대학교 발효생물공학연구소
}

\begin{abstract}
To improve functionality and palatability of Korean Campbell Early wine. Campbell Early and aronia were fermented by either individually or at 5:5 (v/v) mixed culture of Saccharomyces cerevisiae Fermivin and Pichia anomala JK04. Blending was carried out using those two wines with different mixing ratio. Antioxidant activity analysis and sensory evaluation of blending wines were conducted. The Campbell Early wine and aronia wine blended with 9:1 (v/v) ratio showed excellent antioxidant activity and sensory scores. Total anthocyanin compound, DPPH radical scavenging activity and total phenolic compound of blending wines were higher than those of Campbell Early wine (control). Hue and intensity values increased in the order of A, B, C and D, E, F depending on $P$. anomala JK04 use. Anonia wine contributed the increase in a and b values of blending wine. Although blending wines fermented by $P$. anomala JK04 increased small amounts of aldehyde and acid compound, ester compound, the most important factor for wine aroma was also increased sharply. Adding aronia wine fermented by single culture of $P$. anomala JK04 (A, D) got higher color, taste, sourness and overall preference scores than other wines in the sensory evaluation. All of blending wines showed higher flavor scores than control did. This research shows a possibility of blending and utilizing non-Saccharomyces yeast for Korean wine industry.
\end{abstract}

Key words : Campbell Early, aronia, blending wine, Pichia anomala JK04, co-fermentation

\section{서 론}

캠벨얼리(Campbell Early)는 미국에서 개량한 Vitis labrusca 종에 속하는 교잡종으로 우리나라 토양과 기후

*Corresponding author. E-mail : hpark@knu.ac.kr

Phone : 82-53-950-5774, Fax : 82-53-950-6772

Received 15 March 2017; Revised 4 May 2017; Accepted 8 May 2017.

Copyright (c) The Korean Society of Food Preservation. All rights reserved.
조건에 적합하고 완숙이 되면 단맛과 신맛을 나타내며, 미 국 종 특유의 향미가 있어 생과용으로서 사용되는 품종이다 $(1,2)$. 또한 캠벨얼리는 우리나라 포도 재배면적의 $70 \%$ 이 상을 차지하고 있어(3) 국산 와인 제조 시 가장 많이 사용되 는 품종으로 알려져 있으나, 산도가 강하고 당도가 낮아 와인 제조 시 색과 향이 약하고 바람직하지 못한 특유의 호취향(fox aroma)을 내어 포도주 양조에 적합하지 않다고 알려져 있다(4). 따라서 국산 캠벨얼리 와인의 문제점을 해결하기 위하여 발효 과정 중 감산 효과를 지닌 Issatchenkia orientalis와 Saccharomyces cerevisiae의 혼합 
발효(5), 머스트 전처리 과정 중 carbonic maceration 처리(6), Lactobacillus plantarum을 이용한 malolactic fermentation(7) 등을 통해 신맛의 주원인이 되는 malic acid 함량을 낮추는 연구들과 MBA, Stuben, 머루, 블루베리, 복분자, 블랙커런 트 등 다양한 과실의 혼합에 따른 캠벨얼리 와인의 주질 향상(2), S. cerevisiae와 Hanseniaspora uvarum의 혼합발효 를 이용한 캠벨얼리 와인의 주질 향상(8) 등의 연구가 이루 어져 왔다. 하지만 여전히 유럽, 북미, 호주 등에서 생산되는 다양한 수입와인에 비하면 국내 와인의 종류는 매우 제한적 이다. 따라서 국산 와인의 경쟁력 강화를 위해서는 품질 향상과 더불어 와인의 다양성을 확보하는 일이 매우 중요할 것이다.

블렌딩(blending)은 두 가지 이상의 포도 품종을 섞어 독특한 품질의 와인을 만드는 전통적인 와인 양조 기법으로 써 국산 와인의 다양성 확보의 한 방안이 될 수 있다. 유럽에 서는 까베르네 쇼비뇽, 멀롯, 쉬라즈 등 다양한 포도 품종을 블렌딩하여 와이너리 별로 독특한 제품을 생산 및 판매하고 있으며, 국내에서는 캠벨얼리와 머루 등을 혼합하여 발효 시킨 제품 등이 출시되고 있다. 하지만, 최근 안토시아닌 함량이 다른 베리류보다 월등히 높으며 $(9,10)$, 플라보노이 드와 폴리페놀 성분들이 풍부하게 포함되어있어 항산화, 항암, 항염증 등에 효과가 있는 것으로 잘 알려진(11) 아로 니아(Aronia melanocarpa)를 이용한 와인에 대한 연구는 거의 없다. 이는 아로니아가 다양한 생리활성 물질을 함유 하였지만, 신맛과 떫은맛이 강하여 단독으로 가공되었을 때, 소비자의 선호도가 떨어지는 문제점이 있어 생과보다 는 첨가물의 형태로 이용되기 때문이다(12). 아로니아를 첨가물의 형태로 이용하게 되면, 높은 함량의 탄닌으로 인 한 떫은맛을 줄일 수 있으며, 아로니아 자체의 풍부한 생리 활성 기능도 살릴 수 있어 우수한 제품 개발이 가능할 것으 로 보여진다(13).

와인의 품질을 향상시키기 위한 또 다른 방안 중 하나는 non-Saccharomyces를 이용하여 발효하는 방법이다. Non-Saccharomyces 종은 알코올 함량이 낮은 발효 초기 단계에 왕성하게 활동하여 와인에 독특한 풍미와 특성을 부여하는 것으로 알려져 있다(8). 그 중에서 Pichia anomala 는 아세트산, 글리세롤, 에스테르, 아세토인 등의 향기에 관여하는 화합물을 생성한다고 알려져 있다(14). 본 연구실 에서는 선행 연구를 통해 분리한 P. anomala JK04가 감와인 (15)과 빵(16) 발효시에 향기성분이 증가하는 것을 보고한 바 있다.

따라서 본 연구에서는 국산 캠벨얼리 와인의 기능성 및 관능적 특성의 향상을 위하여 캠벨얼리와 아로니아를 $P$. anomala JK04와 S. cerevisiae Fermivin을 이용하여 각각 단독발효 또는 혼합발효를 진행하였으며, 발효가 종료된 각 와인들을 블렌딩하여 그에 따른 블렌딩와인의 품질 특성 을 조사하였다.

\section{재료 및 방법}

실험재료 및 균주의 배양조건

캠벨얼리 와인 발효에 사용한 원료는 2016년 8월말 경북 영천에서 수확한 캠벨얼리 포도를 사용하였고, 아로니아 와인 발효에 사용한 원료는 2015년 8월말 단양에서 수확한 아로니아를 냉장, 냉동 보관하면서 사용하였다. 실험에 사 용한 균주는 경북대학교 식품공학부 미생물공학연구실에 서 분리 및 보관중인 향미 증진 효과가 있는 Pichia anomala JK04(17)와 상업용 와인효모인 Saccharomyces cerevisiae Fermivin(DSM Food Specialties, Delft, Netherlands)을 사용 하였다. 균주 배양을 위하여 YPD 배지 $1.0 \%$ yeast extract, $2.0 \%$ peptone, $2.0 \%$ glucose)를 사용하여 $30^{\circ} \mathrm{C}$ 에서 $150 \mathrm{rpm}$, 24시간 동안 진탕 배양한 후 원심분리기(Hanil Co., SUPRA 22k PLUS, Daejeon, Korea)에서 원심분리 $(8,000 \mathrm{rpm}, 15$ $\mathrm{min}$ )하여 집균한 균체를 실험에 사용하였다.

캠벨얼리 와인 및 아로니아 와인의 제조

캠벨얼리 와인과 아로니아 와인의 제조는 원료인 캠벨얼 리와 아로니아 각각 $5 \mathrm{~kg}$ 을 세척, 제경하고 파쇄한 후 갈변 및 발효 과정 중 잡균의 오염을 방지하기 위하여 potassium metabisulfite $\left(\mathrm{K}_{2} \mathrm{~S}_{2} \mathrm{O}_{5}\right)$ 를 최종농도가 $200 \mathrm{ppm}$ 이 되도록 첨 가하고 $24{ }^{\circ} \mathrm{Brix}$ 가 되도록 설탕을 보당하였다. 그리고 $P$. anomala JK04와 $S$. cerevisiae Fermivin을 주모로 사용하여 $P$. anomala JK04와 S. cerevisiae Fermivin을 각각 단독 발효 한 경우, $P$. anomala JK04와 $S$. cerevisiae Fermivin을 $5: 5(\mathrm{v} / \mathrm{v})$ 의 비율로 혼합 발효한 경우 3 구간의 실험을 진행 하여 캠벨얼리 와인과 아로니아 와인의 발효 특성을 조사하 였다. 발효 온도는 $20^{\circ} \mathrm{C}$ 로 하였고 이산화탄소의 발생이 현 저히 줄고 알코올 함량이 최대치에 도달하는 시점에서 발효 를 종료하였다. 완성된 캠벨얼리 와인과 아로니아 와인은 원심분리 $(8,000 \mathrm{rpm}, 10 \mathrm{~min})$ 하여 $4^{\circ} \mathrm{C}$ 에 저장하며 이후 블렌 딩에 이용하였다.

캠벨얼리 와인 및 아로니아 와인의 발효 특성 분석

캠벨얼리 와인과 아로니아 와인의 발효과정 중 주질 분 석은 발효 중인 와인의 일부를 취하여 원심분리 $(8,000 \mathrm{rpm}$, $10 \mathrm{~min}$ )한 후 얻은 상징액을 이용하였다. $\mathrm{pH}$ 는 상징액 10 $\mathrm{mL}$ 를 $\mathrm{pH}$ meter(Mettler-Toledo CH, MP225K, Seoul, Korea) 를 이용하여 측정하였고, 총산은 $\mathrm{AOAC}$ 방법에 따라 상징 액을 $0.1 \mathrm{~N} \mathrm{NaOH}$ 로 적정하여 캠벨얼리 와인은 tartaric acid, 아로니아 와인은 malic acid 로 환산하여 나타내었다(18). 당도의 측정은 캠벨얼리 와인 및 아로니아 와인을 원심분리 한 상징액을 굴절당도계(ATAGO, Co., N-1a, Kyoto, Japan) 를 사용하여 측정하였다. 환원당 함량 측정은 dinitrosalicylic $\operatorname{acid(DNS)~ㅅㅣㅇㅑㄱㅇㅡㄹ~ㅅㅏㅇㅛㅇㅎㅏㅇㅕ~ㅂㅣㅅㅐㄱ~ㅈㅓㅇㄹㅑㅇㅂㅓㅂㅇㅡㄹㅗ~ㅊㅡㄱㅈㅓㅇㅎㅏㅇㅕㅆㄷㅏ~}$ (19). 즉, 적절한 흡광도 유효범위로 희석된 캠벨얼리 와인 
및 아로니아 와인 상징액 $0.3 \mathrm{~mL}$ 에 DNS 시약 $1 \mathrm{~mL}$ 를 첨가 하고 긇는 물에서 5 분간 반응시킨 후, 증류수 $7 \mathrm{~mL}$ 를 첨가 하여 분광광도계(Shimazdu Co., UV-1700, Kyoto, Japan)를 사용하여 $550 \mathrm{~nm}$ 에서 흡광도를 측정하였고, glucose 표준 곡선으로부터 환원당 함량을 환산하였다. 각 와인의 알코 올 함량은 국세청주류분석규정에 따라 증류한 후 주정계로 측정하였다(20). 생균수 측정은 원심분리하지 않은 시료를 단계 희석하여 YPD 고체 배지에 도말하여 $30^{\circ} \mathrm{C}$ 에서 48 시 간 배양한 후 형성된 군집을 계수하였다(21).

캠벨얼리 와인과 아로니아 와인의 블렌딩

캠벨얼리 와인과 아로니아 와인의 블렌딩 비율은 예비 실험을 통하여 기능성 및 기호성이 우수하다고 판단된 $9: 1(\mathrm{v} / \mathrm{v})$ 의 비율로 선정하였으며, 발효가 종료된 각 와인을 원심분리 $(8,000 \mathrm{rpm}, 10 \mathrm{~min})$ 하여 얻은 상징액으로 블렌딩 하였다. 또한 $P$. anomala JK04와 $S$. cerevisiae Fermivin의 단독 및 혼합 발효에 따른 블렌딩와인의 품질 특성을 알아 보고자 Table 1 과 같이 실험군을 분류하였다. 블렌딩이 완 료된 각 와인들은 $4{ }^{\circ} \mathrm{C}$ 에 보관하면서 각종 이화학적 분석 및 관능평가에 이용하였다.

Table 1. The group of blending wine depending on inoculated yeast strains

\begin{tabular}{cccccc}
\hline \multirow{2}{*}{ Sample } & \multicolumn{5}{c}{ Inoculated yeast } \\
\cline { 2 - 5 } & Campbell Early wine & \multicolumn{3}{c}{ Aronia wine } \\
\cline { 2 - 5 } & $\mathrm{S}^{1)}$ & $\mathrm{P}+\mathrm{S}$ & $\mathrm{S}$ & $\mathrm{P}+\mathrm{S}$ & $\mathrm{P}$ \\
\hline Control & O & & & & \\
A & & 0 & & \\
B & & 0 & & 0 & \\
C & & 0 & 0 & & \\
D & 0 & & & & \\
E & 0 & & & 0 & \\
F & 0 & & 0 & & \\
\hline
\end{tabular}

All the wines were blended with Campbell Early wine and aronia wine with 9:1 $(\mathrm{v} / \mathrm{v})$ ratio.

${ }^{1)}$ S, Saccharomyces cerevisiae Fermivin; P+S, Pichia anomala $\mathrm{JK} 04+\mathrm{S}$. cerevisiae Fermivin; P, $P$. anomala JK04.

\section{총 안토시아닌 함량}

총 안토시아닌 함량은 $0.025 \mathrm{M}$ potassium chloride buffer(pH 1.0)와 0.4 M sodium acetate buffer(pH 4.5)에 시료 를 적정량 희석한 다음 분광광도계를 이용하여 $520 \mathrm{~nm}$ 와 $700 \mathrm{~nm}$ 에서 흡광도를 측정한 후 cyanidin-3-glucoside의 몰 흡광계수 $\left(\varepsilon=26,900 \mathrm{M}^{-1} \mathrm{~cm}^{-1}\right)$ 를 이용하여 아래와 같은 식으 로 정량 분석하였다(22). 대조구는 S. cerevisiae Fermivin으 로 단독 발효시킨 캠벨얼리 와인을 사용하였다.
안토시아닌 함량(cyanidin-3-glu, $\mathrm{mg} / \mathrm{L})=\frac{\mathrm{A} \times \mathrm{MW} \times \mathrm{DF} \times 10^{3}}{\varepsilon \times 1}$

$\mathrm{A}($ Absorbance $)=\left(\mathrm{A}_{520} \mathrm{~mm}-\mathrm{A}_{700} \mathrm{~mm}\right) \mathrm{pH} 1.0-\left(\mathrm{A}_{520 \mathrm{~mm}}-\mathrm{A}_{700 \mathrm{~mm}}\right) \mathrm{pH} 4.5$ MW(Molecular weight of cyanidine-3-glucoside $)=449.2$ $\mathrm{DF}=$ 희석배수 $\varepsilon$ (cyanidin-3-glucoside molar absorbance)=26,900 $\mathrm{M}^{-1} \mathrm{~cm}^{-1}$

총 페놀성 화합물 함량

블렌딩와인의 총 페놀성 화합물의 함량은 Folin-Denis법 에 따라 비색 정량하였다(23). 시료 $2 \mathrm{~mL}$ 에 $50 \%$ phenol reagent(Folin-ciocalteu's reagent) $2 \mathrm{~mL}$ 를 가하여 3 분 동안 실온에 방치한 후 $10 \% \mathrm{Na}_{2} \mathrm{CO}_{3}$ 용액 $2 \mathrm{~mL}$ 를 첨가하여 실온 에서 1 시간 동안 반응시켰다. 그런 다음 반응액을 분광광도 계를 이용하여 $700 \mathrm{~nm}$ 에서 흡광도를 측정하여 tannic acid 를 표준물질로 작성한 표준곡선으로부터 총 페놀성 화합물 함량을 환산하였다.

\section{$\mathrm{DPPH}$ 라디칼 소거능}

블렌딩와인의 DPPH 라디칼 소거능 분석은 96 well plate 에 순차적으로 희석된 시료 $1 \mu \mathrm{L}$ 를 넣은 후, $199 \mu \mathrm{L}$ 의 0.1 $\mathrm{mM}$ DPPH working solution(4 mg DPPH/100 mL 50\% EtOH) 을 첨가한 다음, 실온에서 빛이 없는 조건으로 10 분간 반응 시킨 후, multi label counter(Victor3, Perkin Elmer, Waltham, MA, USA)를 이용하여 $517 \mathrm{~nm}$ 에서 흡광도를 측정하였다. 이때, 표준물질로는 ascorbic acid를 사용하였으며 control은 ethanol을 사용하여 동일한 방법으로 측정하였다. 대조구로 는 S. cerevisiae Fermivin으로 단독 발효된 캠벨얼리 와인을 사용하였다(24).

색도 분석

블렌딩와인의 hue와 intensity 분석은 분광광도계를 이용 하여 $420 \mathrm{~nm}$ 와 $520 \mathrm{~nm}$ 에서 흡광도를 측정한 다음, hue 값은 $420 \mathrm{~nm}$ 와 $520 \mathrm{~nm}$ 의 흡광도 비율 $(420 / 520 \mathrm{~nm})$ 로 하였 으며, intensity 값은 $420 \mathrm{~nm}$ 와 $520 \mathrm{~nm}$ 의 합 $(420+520 \mathrm{~nm})$ 으 로 나타내었다(25). 블렌딩와인의 색도는 색차계(CM-3600d, Konica Minolta, Osaka, Japan)를 이용하여 측정하였으며, $\mathrm{L}$ (명도), $\mathrm{a}$ (적색도), $\mathrm{b}$ (황색도) 값으로 나타내었다.

\section{유리당 및 유기산 함량}

유리당과 유기산 함량은 블렝딩 와인을 membrane filter(Millex-HV $0.45 \mu \mathrm{m}$, Millipore Co., Bedford, USA)로 여과시킨 후 high performance liquid chromatography (Shimadzu Co., Model Prominence, Seoul, Korea)를 이용하 여 분석하였다 $(7,26)$. 유리당 column은 Sugar-Pak $\mathrm{I}(\phi$ $6.5 \times 300 \mathrm{~mm}$ ) 을 사용하였고, column 온도는 $90^{\circ} \mathrm{C}$ 로 설정하 였다. 유기산 column은 PL Hi-Plex H $(\$ 7.7 \times 300 \mathrm{~mm})$ 를 사용 하였고, column 온도는 $65^{\circ} \mathrm{C}$ 로 설정하였다. 


\section{휘발성 향기 성분}

1 휘발성 향기 성분은 FID가 장착된 gas chromatograph mass spectrometry(Agilent 7890A, Santa Clara, CA, USA)를 사용하여 분석하였고, 향기성분의 포집은 $\mathrm{SPME}$ fiber (50/30 $\mu \mathrm{m}$ DVB/CAR/PDMS, Supelco, Bellefonte, PA, USA) 를 사용하여 head-space 분석법으로 분석하였다(7). 전처리 방법으로는 headspace vial(20 mm, PTFE/silicon septum, magnetic cap)에 시료 $5 \mathrm{~mL}$ 와 $25 \% \mathrm{NaCl}(\mathrm{w} / \mathrm{v})$ 을 첨가하여 완벽하게 밀봉한 후 $35^{\circ} \mathrm{C}$ 에서 자력교반기로 20 분 동안 교반 하여 시료와 headspace의 휘발성 성분이 평형이 이루어졌 을 때 SPME fiber를 주입하여 40분간 향기성분을 포집하였 다. 휘발성 향기 성분 분석을 위한 Column은 DB-WAX(60 $\mathrm{m} \times 250 \mu \mathrm{m} \times \phi 0.25 \mathrm{~mm}$, Waters)를 사용하였고 Column온도 는 $40^{\circ} \mathrm{C}(2 \mathrm{~min}), 220^{\circ} \mathrm{C}\left(2{ }^{\circ} \mathrm{C} / \mathrm{min}\right), 240^{\circ} \mathrm{C}\left(20^{\circ} \mathrm{C} / \mathrm{min}\right), 240^{\circ} \mathrm{C}(5$ $\mathrm{min}$ )으로 설정하였다. Injector 온도는 $240^{\circ} \mathrm{C}$, carrier gas는 $\mathrm{He}$ 를 사용하였다. 휘발성 향기 성분의 분석을 위해 사용된 library는 Wiley9Nist0.8(Wiley9Nist0.8 Library, mass spectral search program, version 5.0, Ringoes, NJ, USA)이었 다(7).

\section{관능검사}

블렌딩와인의 관능검사는 대학생과 대학원생 중 본 실험 에 관심있는 학생 20 명을 선발하여 무작위로 제시된 시료 에 대하여 색, 향, 맛, 신맛 및 전반적인 기호도에 대하여평 가하였다. 7점 척도법으로 평가하였으며, 7점은 매우 좋다, 1점은 매우 나쁘다로 평가하였다.

\section{통계처리}

모든 실험 결과는 3회 반복 실시하여 실험 결과를 평균 표준편차로 나타내었고 실험군 간의 유의성을 검정하기 위하여 SAS 통계처리(Statstical Analysis System, SAS Insititute Inc., Cary, USA)를 이용한 분산분석(ANOVA)과 Duncan의 다중범위검증(Duncan's multiple range test, $\mathrm{p}<0.05)$ 으로 유의성을 검증하였다(26).

\section{결과 및 고찰}

캠벨얼리 와인 및 아로니아 와인의 발효 특성

캠벨얼리와 아로니아를 각각 S. cerevisiae Fermivin과 $P$.
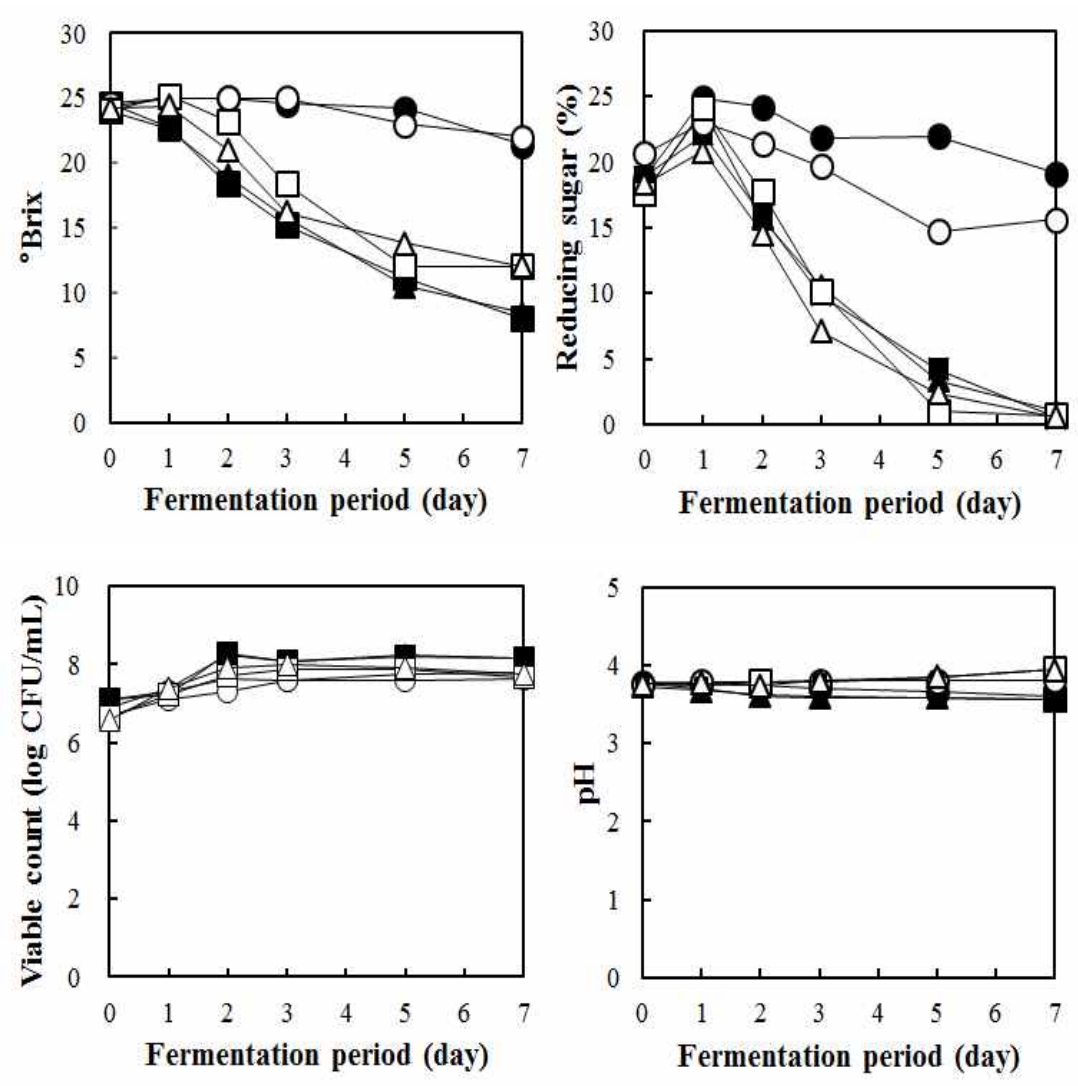

Fig. 1. Changes in the soluble solid, reducing sugar, alcohol contents, viable count, $\mathrm{pH}$ and total acid content during alcohol fermentation of Campbell Early (black symbol) and aronia (white symbol) inoculated with Saccharomyces cerevisiae Fermivin $(\boldsymbol{\Lambda}, \triangle)$, Pichia anomala JK04 $(\mathbf{O}, \bigcirc)$ or mixed culture of those two strains with $5: 5(\mathrm{v} / \mathrm{v})$ ratio $(\boldsymbol{\square}, \square)$.

All the data were expressed as mean \pm SD $(n=3)$. 
anomala JK04로 7일간 단독발효 또는 혼합발효하는 과정 중 당도, 환원당, 알코올, 생균수, $\mathrm{pH}$, 총산도의 변화를 Fig. 1 에 나타내었다. 모든 시험구에서 발효가 진행될수록 생균 수가 증가하여 발효 2일차부터 $7 \log \mathrm{CFU} / \mathrm{mL}$ 이상의 높은 생육도 값을 나타내었다. 당도와 환원당 분석 결과, $P$. anomala JK04로 단독 발효한 캠벨얼리 와인과 아로니아 와인 모두에서 해당 균주의 낮은 발효력으로 인해 당 분해 가 제대로 되지 않는 결과를 나타내었고, 나머지 시험구에 서는 캠벨얼리 와인의 최종 당도가 약 $8.0^{\circ} \mathrm{Brix}$, 아로니아 와인의 최종 당도가 약 $12.0{ }^{\circ} \mathrm{Brix}$ 로 나타났는데, 이는 원료 의 당 조성 차이에 기인하는 것으로 여겨진다. 알코올 함량 분석 결과, S. cerevisiae Fermivin으로 단독발효한 캠벨얼리 와인, 아로니아 와인과 $S$. cerevisiae Fermivin으로 단독발효 한 캠벨얼리 와인은 발효가 빨리 진행되어 최종적으로 캠벨 얼리와인은 $14.0 \%$, 아로니아 와인은 $12.0 \%$ 의 알코올 함량 을 나타내었다. P. anomala JK04와 S. cerevisie Fermivin으 로 혼합발효한 아로니아 와인은 상대적으로 발효가 늦게 진행되었지만 최종적으로 $12 \%$ 의 알코올 함량을 나타내었 다. 반면, $P$. anomala JK04로 단독발효한 와인들은 최종 알코올 농도가 3.7-4.0\%로 매우 낮게 나타났다. NonSaccharomyces 효모를 이용하여 포도주 발효를 진행한 Domizio 등(27)의 연구에 따르면, P. anomala를 단독으로 60 일간 포도주 발효시켰을 때, 포도주의 알코올 함량이 $6.94 \%$ 로 매우 낮게 나타났다고 보고하였고, Kwon(17)의 연구에서도 P. anomala JK04 단독으로 감와인을 발효시켰 을 때, 약 $4 \%$ 정도의 낮은 알코올 함량을 얻는 결과를 나타 내었다고 보고하였다. 이는 P. anomala의 알코올 생성능이 S. cerevisiae에 비하여 현저히 떨어지기 때문이며, 본 연구 에서도 앞선 연구들과 비슷한 결과를 나타내었다.

캠벨얼리 와인과 아로니아 와인의 초기 $\mathrm{pH}$ 는 3.73-3.78 이었으며, 캠벨얼리 와인은 발효가 진행될수록 서서히 감 소하여 3.57-3.61을 나타내었고, 아로니아 와인은 서서히
증가하여 3.81-3.94를 나타내었다. 포도주 발효과정에서 권 장되는 $\mathrm{pH}$ 는 2.8-4.0 범위로서 이보다 높을 경우 잡균의 오염 위험이 존재하며 $\mathrm{pH}$ 가 낮을수록 미생물에 대한 저항 력이 강해지나 $\mathrm{pH} 3.0$ 이하에서는 발효가 저해되며, 신맛의 증가로 인해 제품의 관능적 품질이 저하되는 것으로 보고되 어 있다(17,28). 캠벨얼리 와인의 경우 $\mathrm{pH}$ 는 3.3-3.6 정도가 바람직하다고 보고된 바 있으며(29), 캠벨얼리 와인과 아로 니아와인 모두 권장 $\mathrm{pH}$ 범위 안에 들어가는 결과를 나타내 었다. 발효 과정 중 총산의 변화 관찰 결과, 캠벨얼리 와인의 초기 총산도는 $0.34-0.39 \%$, 아로니아 와인의 초기 총산도는 $0.57-0.61 \%$ 로써 아로니아 와인의 초기 총산도가 상대적으 로 높게 나타났다. 캠벨얼리 와인의 경우, 발효가 진행되면 서 P. anomala JK04 단독발효구에서는 총산이 상대적으로 낮게 증가되어 최종적으로 $0.53 \%$ 를 나타내었고, $S$. cerevisiae Fermivin 단독발효구와 혼합발효구에서는 발효 가 왕성하게 진행되기 시작한 발효 2 일차부터 급격하게 증가하여 최종적으로 $0.66-0.69 \%$ 의 총산도를 나타내었다. 아로니아 와인의 경우, 발효과정 중 총산도가 서서히 증가 하여 0.68-0.71\%로 P. anomala JK04로 단독발효된 캠벨얼 리 와인을 제외한 모든 와인에서 비슷한 총산도 값을 나타 내었다.

\section{최적 블렌딩 비율의 선정}

캠벨얼리 와인과 아로니아 와인의 블렌딩 비율을 설정하 기 위하여, 예비실험으로 $S$ cerevisiae Fermivin으로 단독발 효시킨 캠벨얼리 와인에 동일 균주로 발효시킨 아로니아 와인을 각각 $5 \%, 10 \%, 20 \%(\mathrm{v} / \mathrm{v})$ 블렌딩하였다. 블렌딩 결 과, 아로니아 와인을 첨가하지 않은 대조구 $(46.88 \%)$ 보다 $10 \%, 20 \%$ 첨가구에서 $\mathrm{DPPH}$ 라디칼 소거능이 60.27-62.74\%로 크게 증가한 것으로 나타났으나 두 첨가구 사이에 유의적인 차이를 보이진 않았으며, 아로니아 특유 의 떫은맛으로 인해 $20 \%$ 첨가구에서 $10 \%$ 첨가구보다 맛,

Table 2. Preliminary experiments for selecting an optimal blending ratio

\begin{tabular}{|c|c|c|c|c|}
\hline \multirow{2}{*}{ Properties } & \multicolumn{4}{|c|}{ Ratio of Campbell Early and aronia wine (\%) } \\
\hline & 100:0 & $95: 5$ & $90: 10$ & $80: 20$ \\
\hline DPPH free radical scavenging activity $(\%)$ & $46.88 \pm 0.55^{1 /(2)}$ & $52.07 \pm 1.04^{\mathrm{b}}$ & $60.27 \pm 1.25^{\mathrm{a}}$ & $62.74 \pm 1.67^{\mathrm{a}}$ \\
\hline Total anthocyanin compound $(\mathrm{g} / \mathrm{L})$ & $2.30 \pm 0.02^{\mathrm{c}}$ & $3.07 \pm 0.05^{b}$ & $3.29 \pm 0.18^{b}$ & $3.86 \pm 0.10^{\mathrm{a}}$ \\
\hline Total phenolic compound (\%) & $0.16 \pm 0.01^{\mathrm{d}}$ & $0.19 \pm 0.00^{\mathrm{c}}$ & $0.22 \pm 0.01^{b}$ & $0.27 \pm 0.01^{\mathrm{a}}$ \\
\hline \multicolumn{5}{|l|}{ Sensory evaluation } \\
\hline Color & $5.63 \pm 0.22^{\mathrm{a}}$ & $5.50 \pm 0.20^{\mathrm{a}}$ & $5.57 \pm 0.21^{\mathrm{a}}$ & $5.83 \pm 0.21^{\mathrm{a}}$ \\
\hline Flavor & $5.43 \pm 0.22^{\mathrm{a}}$ & $5.23 \pm 0.20^{\mathrm{a}}$ & $5.40 \pm 0.20^{\mathrm{a}}$ & $4.37 \pm 0.14^{b}$ \\
\hline Taste & $4.80 \pm 0.24^{b}$ & $5.00 \pm 0.20^{\mathrm{b}}$ & $5.67 \pm 0.16^{\mathrm{a}}$ & $4.40 \pm 0.22^{b}$ \\
\hline Sourness & $4.47 \pm 0.23^{\mathrm{a}}$ & $4.60 \pm 0.21^{\mathrm{a}}$ & $5.00 \pm 0.23^{\mathrm{a}}$ & $4.57 \pm 0.21^{\mathrm{a}}$ \\
\hline Overall preference & $5.13 \pm 0.21^{\mathrm{b}}$ & $5.47 \pm 0.16^{\mathrm{ab}}$ & $5.73 \pm 0.16^{\mathrm{a}}$ & $4.53 \pm 0.14^{\mathrm{c}}$ \\
\hline
\end{tabular}

\footnotetext{
${ }^{1)}$ The values were expressed as mean $\pm \mathrm{SD}(\mathrm{n}=3)$.

${ }^{2)}$ Different letters within the same row indicate significant difference $(\mathrm{p}<0.05)$.
} 
신맛, 전반적인 기호도 등에서 관능점수가 떨어지는 결과 를 얻었다(Table 2). 예비 실험 결과를 바탕으로 캠벨얼리 와인과 아로니아 와인의 블렌딩 비율을 $9: 1(\mathrm{v} / \mathrm{v})$ 로 설정하 였으며, 알코올 함량이 $4 \%$ 이하로 매우 낮았던 P. anomala $\mathrm{JK} 04$ 로 단독발효한 캠벨얼리 와인을 제외한 5 가지 와인을 각각 블렌딩하였다. 대조구로는 S. cerevisiae Fermivin으로 단독발효한 캠벨얼리 와인을 사용하였다(Table 1).

\section{항산화 활성 비교}

블렌딩와인의 기능성을 평가하기 위하여 총 안토시아닌 함량, DPPH 라디칼 소거능, 총 페놀성 화합물 함량을 측정 하였으며, 그 결과를 Fig. 2에 나타내었다. 총 안토시아닌 함량 분석 결과, 대조구의 총 안토시아닌 함량은 $1.668 \mathrm{~g} / \mathrm{L}$ 였으나, 블렌딩 와인들의 총 안토시아닌 함량은 2.054-2.421 $\mathrm{g} / \mathrm{L}$ 로 크게 증가한 것을 확인하였고, 이는 아로니아에 함유 된 풍부한 안토시아닌의 영향으로 보여진다. 또한 $S$. cerevisiae Fermivin 로만 발효된 블렌딩와인(F)보다 $P$. anomala JK04이 발효에 이용된 와인들에서(A-E) 상대적으 로 더 높은 안토시아닌 함량을 나타내었으며, 이는 $P$. anomala JK04의 발효 특성 때문으로 생각된다. 블렌딩와인 의 DPPH 라디칼 소거능 분석 결과, 대조구는 $46.88 \%$ 를 나타내었으나 블렌딩와인들은 61.96-63.88\%로 모든 블렌 딩와인에서 DPPH 라디칼 소거능이 크게 증가한 것을 확인 하였다. 총 페놀성화합물 함량 분석 결과에서도 모든 블렌 딩와인에서 대조구 $(0.155 \%)$ 보다 약간 높은 $0.160-0.170 \%$ 의 총 페놀성 화합물 함량을 나타내었다. 각각 $2,4,6,8 \%$ 의 아로니아 분말을 첨가하여 쿠키를 제조한 Lee와 Yoon(30) 의 연구에서도 아로니아 첨가에 따라 DPPH 라디칼 소거능, $\mathrm{ABTS}$ 라디칼 소거능, 총 페놀성 화합물의 함량이 증가하는 경향을 나타내었으며, 본 연구의 예비실험 결과와 마찬가 지로 아로니아의 첨가량이 일정 수준 이상이 되었을 때, 아로니아 첨가 쿠키의 항산화 활성 증가폭이 크게 떨어진다 고 보고하였다.

\section{유리당 및 유기산 함량 분석}

블렌딩와인의 유리당 및 유기산 조성을 분석한 결과를 Table 3에 나타내었다. 블렌딩와인의 유리당 분석 결과, sucrose는 대조구를 포함한 모든 시험구에서 대부분 소모된 결과를 나타내었으나, P. anomala JK04로 단독발효한 아로 니아 와인을 첨가한 시험구(A, D)에서는 glucose와 fructose 함량이 다른 구에 비하여 많이 남아있었다. 이는 아로니아 와인의 알코올 발효 동안 $P$. anomala $\mathrm{JK} 04$ 가 발효를 종료하 지 못해 남은 잔당으로 보여진다. 또한 $S$. cerevisiae Fermivin과 P. anomala JK04로 혼합발효한 캠벨얼리 와인 을 사용한 또 다른 시험구 $(\mathrm{B}, \mathrm{C})$ 에서도 fructose가 대조구에 비하여 0.268-0.275\% 높게 측정되었다. 블렌딩와인의 유기 산 분석 결과, malic acid를 제외한 모든 시험구에서 유의적
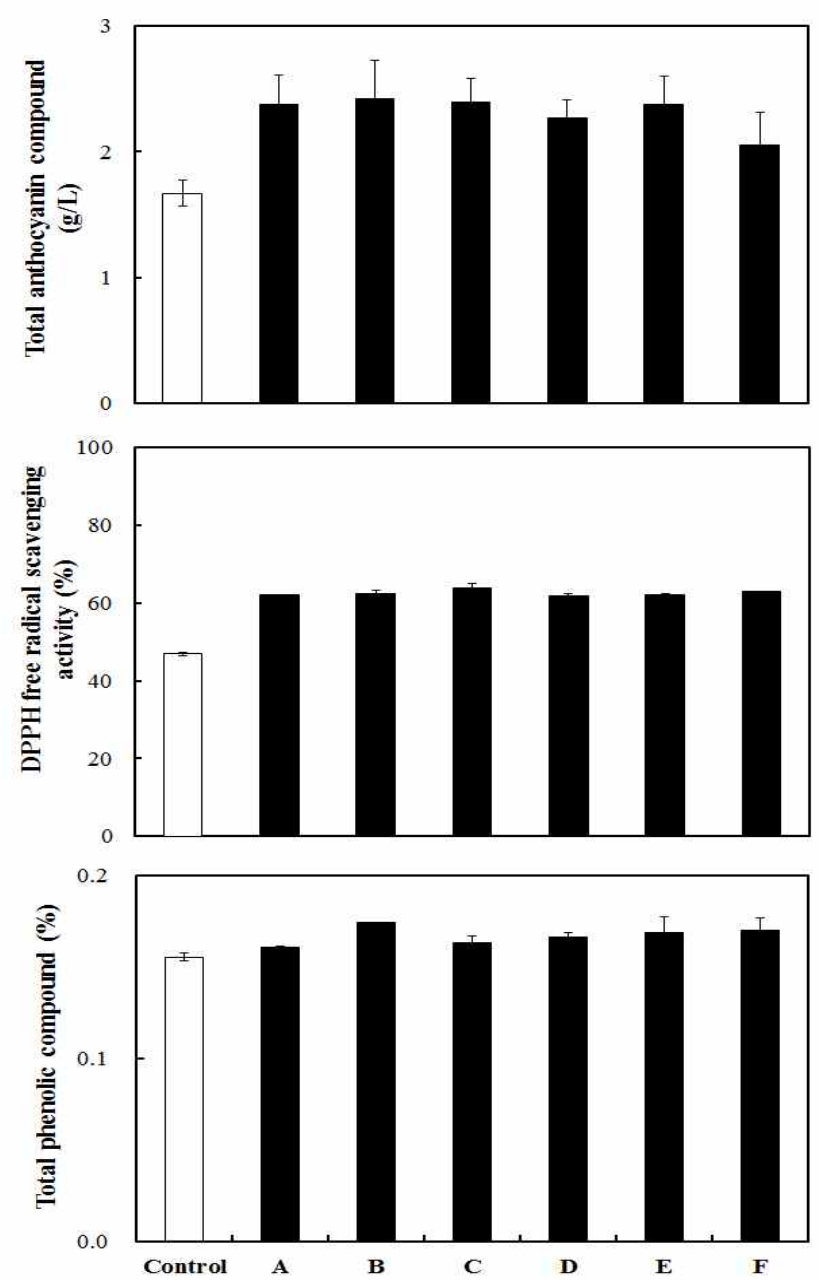

Fig. 2. Total anthocyanin compound, DPPH free radical scavenging activity and total phenolic compound contents of various wines blended with Campbell Early and aronia fermented by single or mixed culture of Saccharomyces cerevisiae Fermivin and Pichia anomala JK04.

All the data were expressed as mean $\pm \mathrm{SD}(\mathrm{n}=3)$.

인 차이를 보이지 않았으나, malic acid의 경우에 블렌딩와 인에서 대조구보다 많게는 2.5 배 이상의 함량을 나타내었 다. 특히, S. cerevisiae Fermivin과 P. anomala JK04로 혼합 발효한 캠벨얼리를 사용한 시험구(A-C)에서 malic acid 함 량이 높았으며, P. anomala JK04로 단독발효한 아로니아 와인을 사용한 시험구(D)에서도 malic acid 함량이 높게 측정되었다.

\section{색도분석}

블렌딩와인의 항산화 활성 이외에도 소비자 기호를 좌우 하는 관능적 특성을 비교하기 위하여 색도, 휘발성 향기성 분, 관능검사 결과를 비교 분석하였다. 블렌딩와인의 색도 분석을 위하여 적포도주의 색도와 갈변도를 평가하기 위해 이용되는 hue value, intensity value, Hunter's color value를 
측정한 결과를 Table 4에 나타내었다. Hue value의 경우 $S$. cerevisiae Fermivin과 P. anomala JK04로 혼합발효한 캠벨얼리를 사용한 시험구(A-C)에서 0.9 이하를 나타내었 으나 대조구를 포함한 나머지 구에서는 0.906-0.950으로 더 높은 값을 나타내었다. 또한 아로니아 와인의 사용 균주 여부를 비교하였을 때도 P. anomala JK04 사용 여부에 따라 $\mathrm{A}, \mathrm{B}, \mathrm{C}$ 와 D, E, F 순으로 hue value가 증가하였다. Intensity value의 경우 역시 $\mathrm{E}$ 시험구를 제외한 나머지 시험구에서는 hue value와 비슷한 경향을 나타내었으며, 혼합발효한 캠벨 얼리 와인을 사용하였을 때, 대조구를 포함한 나머지 구보 다 intensity 값이 감소하는 것을 볼 수 있었다. Hunter's color value의 경우, L value에서는 사용균주 여부에 따른 특별한 경향을 보이진 않았으나, 적색도를 나타내는 a value 의 경우 아로니아 와인을 블렌딩하였을 때, 모든 시험구에 서 대조구보다 수치가 증가하였으며, 황색도를 나타내는 $\mathrm{b}$ value의 경우 $\mathrm{A}$ 시험구를 제외한 나머지 구에서 모두 대조구보다 수치가 증가하여 아로니아 와인 첨가에 따라 대조구인 캠벨얼리 와인보다 짙은 색의 와인을 얻을 수 있었다.
휘발성 향기 성분

블렌딩와인의 휘발성 향기 성분의 함량은 Table 5 에 나타 내었다. 향기 성분은 와인의 품질을 결정하는 중요한 요소 로, 향미를 이루는 물질인 esters, aldehydes, ketones, terpenes, acids, alcohols, sulfur compounds 등의 서로 다른 화합물간의 복합적인 작용에 의해 형성된다(31). 블렌딩와 인의 향기성분 분석결과 aldehyde 2 종, acid 2 종과 함께 14 종 의 ester가 검출되었다. 와인의 향미에 부정적인 영향을 미 치는 aldehyde류의 함량은 대부분의 블렌딩와인에서 대조 구보다 약간 증가하였으며, 아로니아 와인에서 P. anomala JK04 사용여부에 따라 benzaldehyde의 함량이 A, B, C와 $\mathrm{D}, \mathrm{E}, \mathrm{F}$ 순으로 감소하였고, acetaldehyde 역시 $S$. cerevisiae Fermivin으로 단독발효한 아로니아 와인을 사용하였을 때, 감소하는 경향을 나타내었다. 따라서 아로니아 와인에서 P. anomala JK04가 aldehyde류의 생성에 영향을 주었을 것으로 판단된다. Acid 분석 결과 역시, 전반적으로 아로니 아 와인에서 P. anomala JK04 사용이 증가함에 따라 높게 검출되는 경향을 나타내었다. 와인의 향기성분에서 가장 큰 역할을 한다고 알려진 ester의 분석 결과, 혼합발효한캠 벨얼리를 사용한 시험구(A-C)에서 대조구와 비교하여

Table 3. Free sugar and organic acid contents of blended wines after inoculated with mixed culture of wine yeasts after alcohol fermentation

\begin{tabular}{ccccccccc}
\hline Sample & Sucrose & Glucose & Fructose & Citric acid & Tartaric acid & Malic acid & Succinic acid & Acetic acid \\
\hline Control & $0.033 \pm 0.005^{1,2) 2}$ & $0.019 \pm 0.004^{\mathrm{b}}$ & $0.052 \pm 0.005^{\mathrm{d}}$ & $0.012 \pm 0.007^{\mathrm{a}}$ & $0.023 \pm 0.005^{\mathrm{a}}$ & $0.030 \pm 0.006^{\mathrm{b}}$ & $0.023 \pm 0.004^{\mathrm{a}}$ & $0.002 \pm 0.001^{\mathrm{a}}$ \\
A & $0.029 \pm 0.006^{\mathrm{a}}$ & $0.530 \pm 0.006^{\mathrm{a}}$ & $1.393 \pm 0.004^{\mathrm{a}}$ & $0.011 \pm 0.007^{\mathrm{a}}$ & $0.019 \pm 0.005^{\mathrm{a}}$ & $0.078 \pm 0.007^{\mathrm{a}}$ & $0.023 \pm 0.005^{\mathrm{a}}$ & $0.004 \pm 0.003^{\mathrm{a}}$ \\
B & $0.030 \pm 0.007^{\mathrm{a}}$ & $0.021 \pm 0.006^{\mathrm{b}}$ & $0.341 \pm 0.008^{\mathrm{c}}$ & $0.013 \pm 0.006^{\mathrm{a}}$ & $0.021 \pm 0.007^{\mathrm{a}}$ & $0.053 \pm 0.007^{\mathrm{ab}}$ & $0.035 \pm 0.006^{\mathrm{a}}$ & $0.009 \pm 0.008^{\mathrm{a}}$ \\
C & $0.030 \pm 0.007^{\mathrm{a}}$ & $0.022 \pm 0.008^{\mathrm{b}}$ & $0.348 \pm 0.007^{\mathrm{c}}$ & $0.011 \pm 0.007^{\mathrm{a}}$ & $0.024 \pm 0.008^{\mathrm{a}}$ & $0.052 \pm 0.007^{\mathrm{ab}}$ & $0.023 \pm 0.005^{\mathrm{a}}$ & $0.009 \pm 0.008^{\mathrm{a}}$ \\
D & $0.035 \pm 0.007^{\mathrm{a}}$ & $0.527 \pm 0.005^{\mathrm{a}}$ & $1.093 \pm 0.005^{\mathrm{b}}$ & $0.011 \pm 0.007^{\mathrm{a}}$ & $0.010 \pm 0.006^{\mathrm{a}}$ & $0.077 \pm 0.005^{\mathrm{a}}$ & $0.020 \pm 0.008^{\mathrm{a}}$ & $0.006 \pm 0.005^{\mathrm{a}}$ \\
E & $0.036 \pm 0.007^{\mathrm{a}}$ & $0.019 \pm 0.007^{\mathrm{b}}$ & $0.073 \pm 0.008^{\mathrm{d}}$ & $0.011 \pm 0.007^{\mathrm{a}}$ & $0.024 \pm 0.008^{\mathrm{a}}$ & $0.033 \pm 0.007^{\mathrm{b}}$ & $0.024 \pm 0.005^{\mathrm{a}}$ & $0.006 \pm 0.005^{\mathrm{a}}$ \\
F & $0.035 \pm 0.005^{\mathrm{a}}$ & $0.017 \pm 0.007^{\mathrm{b}}$ & $0.073 \pm 0.008^{\mathrm{d}}$ & $0.014 \pm 0.008^{\mathrm{a}}$ & $0.022 \pm 0.007^{\mathrm{a}}$ & $0.033 \pm 0.005^{\mathrm{b}}$ & $0.024 \pm 0.005^{\mathrm{a}}$ & $0.001 \pm 0.001^{\mathrm{a}}$ \\
\hline
\end{tabular}

${ }^{1)}$ The values were expressed as mean $\pm \mathrm{SD}(\mathrm{n}=3)$.

${ }^{2)}$ Different letters within the same column indicate significant difference $(\mathrm{p}<0.05)$.

Table 4. Color values of blended wines inoculated with mixed culture of wine yeasts after alcohol fermentation

\begin{tabular}{|c|c|c|c|c|c|}
\hline \multirow{2}{*}{ Sample } & \multicolumn{2}{|c|}{ Color } & \multicolumn{3}{|c|}{ Hunter's color values } \\
\hline & Hue & Intensity & $\mathrm{L}$ & $\mathrm{a}$ & $\mathrm{b}$ \\
\hline Control & $0.916 \pm 0.031^{1 \mathrm{a} 22)}$ & $4.851 \pm 0.013^{\mathrm{c}}$ & $42.72 \pm 0.01^{\mathrm{c}}$ & $22.60 \pm 0.01^{\mathrm{d}}$ & $10.03 \pm 0.02^{\text {cd }}$ \\
\hline $\mathrm{A}$ & $0.867 \pm 0.035^{\mathrm{a}}$ & $4.669 \pm 0.016^{\mathrm{d}}$ & $43.04 \pm 0.01^{b}$ & $23.13 \pm 0.05^{b}$ & $9.98 \pm 0.03^{\mathrm{d}}$ \\
\hline B & $0.890 \pm 0.019^{\mathrm{a}}$ & $4.807 \pm 0.047^{\mathrm{c}}$ & $40.04 \pm 0.01^{g}$ & $22.82 \pm 0.06^{\mathrm{c}}$ & $10.25 \pm 0.04^{\mathrm{bc}}$ \\
\hline $\mathrm{C}$ & $0.894 \pm 0.033^{\mathrm{a}}$ & $4.825 \pm 0.019^{c}$ & $42.44 \pm 0.01^{\mathrm{e}}$ & $23.00 \pm 0.01^{\mathrm{bc}}$ & $10.21 \pm 0.01^{\mathrm{bc}}$ \\
\hline $\mathrm{D}$ & $0.906 \pm 0.033^{\mathrm{a}}$ & $4.889 \pm 0.018^{\mathrm{bc}}$ & $42.63 \pm 0.01^{\mathrm{d}}$ & $23.19 \pm 0.04^{\mathrm{b}}$ & $10.33 \pm 0.02^{b}$ \\
\hline E & $0.918 \pm 0.033^{\mathrm{a}}$ & $5.087 \pm 0.017^{\mathrm{a}}$ & $43.24 \pm 0.01^{\mathrm{a}}$ & $23.17 \pm 0.02^{\mathrm{b}}$ & $10.05 \pm 0.01^{\mathrm{cd}}$ \\
\hline $\mathrm{F}$ & $0.950 \pm 0.037^{\mathrm{a}}$ & $4.943 \pm 0.021^{\mathrm{b}}$ & $42.29 \pm 0.00^{\mathrm{f}}$ & $23.56 \pm 0.02^{\mathrm{a}}$ & $10.80 \pm 0.01^{\mathrm{a}}$ \\
\hline
\end{tabular}

\footnotetext{
${ }^{1)}$ All the data were expressed as mean $\pm \mathrm{SD}(\mathrm{n}=3)$.

${ }^{2)}$ Different letters within the same column indicate significant difference $(\mathrm{p}<0.05)$
} 
methyl acetate, ethyl acetate, ethyl butyrate, n-hexyl acetate, ethyl heptanoate, ethyl octanoate, ethyl benzoate, methyl salicylate, phenethyl acetate의 함량이 큰 폭으로 증가하였 고, ethyl hexanoate를 제외한 나머지 ester류의 함량도 소폭 으로 증가하였다. 반면 $S$. cerevisiae Fermivin으로 단독발효 한 캠벨얼리 와인을 사용한 시험구(D-F)의 경우에는 대조
구와 비교하여 ester 함량이 소폭 증가하거나 일부 감소하는 경향을 나타내었는데, 이는 블렌딩 과정에서 캠벨얼리 와 인의 비율이 $90 \%$ 로 블렌딩와인의 대부분을 차지하여 발효 과정 중 ester 화합물 생성에 관여하는 P. anomala JK04가 블렌딩와인에 미치는 영향력이 커졌기 때문으로 보여진다. $S$. cerevisiae Fermivin과 P. anomala JK04로 감와인을 혼합

Table 5. Volatile aromatic compounds in blended wines inoculated with mixed culture of wine yeasts after alcohol fermentation

(unit: peak area value/1,000)

\begin{tabular}{|c|c|c|c|c|c|c|c|c|c|}
\hline \multirow{2}{*}{ Compound names } & \multirow{2}{*}{ Odor description } & \multicolumn{7}{|c|}{ Sample } & \multirow{2}{*}{ Ref. } \\
\hline & & Control & $\mathrm{A}$ & $\mathrm{B}$ & $\mathrm{C}$ & $\mathrm{D}$ & $\mathrm{E}$ & $\mathrm{F}$ & \\
\hline \multicolumn{10}{|l|}{ Aldehydes } \\
\hline Acetaldehyde & & 406 & 659 & 681 & 605 & 520 & 559 & 430 & \\
\hline Benzaldehyde & Almond, burnt sugar & 916 & 1355 & 978 & 812 & 1271 & 1058 & 982 & [33] \\
\hline \multicolumn{10}{|l|}{ Acids } \\
\hline Acetic acid & Pungent & 693 & 1301 & 745 & 548 & 1148 & 641 & 715 & [34] \\
\hline Octanoic acid & Candy, caramelized, perfumy, fruity, peachy & 1663 & 1092 & 1007 & 798 & 1959 & 1850 & 1449 & [33] \\
\hline \multicolumn{10}{|l|}{ Esters } \\
\hline Methyl acetate & Banana, pineapple & 229 & 336 & 280 & 260 & 231 & 213 & 223 & [35] \\
\hline Ethyl acetate & Fruity, sweet & 83691 & 130774 & 140934 & 140621 & 81971 & 85116 & 67744 & [36] \\
\hline Ethyl butyrate & Fruity, papaya, butter, sweet, apple, perfumed & 836 & 1607 & 1296 & 1658 & 945 & 1046 & 815 & [37] \\
\hline Isoamyl acetate & Fresh, banana, sweet & 31698 & 38322 & 37983 & 32018 & 33930 & 35474 & 32169 & [34] \\
\hline Ethyl hexanoate & Fruity, apple, banana & 27957 & 23675 & 30886 & 22386 & 32179 & 38861 & 25812 & {$[33,37]$} \\
\hline n-Hexyl acetate & Fruity, apple, pear & 1447 & 2830 & 2473 & 2868 & 1793 & 1660 & 1713 & [38] \\
\hline Ethyl heptanoate & & 978 & 1078 & 1295 & 1286 & 965 & 1062 & 1021 & \\
\hline Ethyl octanoate & Pineapple, pear & 31677 & 47357 & 58723 & 39825 & 34582 & 38250 & 29639 & [33] \\
\hline Ethyl decanoate & Fatty acids, fruity, apple, solvent & 6368 & 7063 & 9627 & 6523 & 6913 & 6863 & 6245 & [37] \\
\hline Ethyl benzoate & Camomile, flower, celery & 1725 & 2144 & 3802 & 3184 & 1466 & 1649 & 2132 & [34] \\
\hline Ethyl decenoate & Sweet, fatty, nut-like & 411 & 529 & 982 & 502 & 430 & 543 & 299 & [15] \\
\hline Methyl salicylate & Wintergreen, peppermint & 2063 & 3752 & 3989 & 3879 & 2607 & 1551 & 2296 & {$[15]$} \\
\hline Phenethyl acetate & Floral, fruity, sweet & 2062 & 3507 & 4041 & 3074 & 2124 & 1636 & 2031 & [34] \\
\hline
\end{tabular}

Table 6. Sensory scores of blended wines inoculated with mixed culture of wine yeasts after alcohol fermentation

\begin{tabular}{cccccc}
\hline Sample & Color & Flavor & Taste & Sourness & Overall preference \\
\hline Control & $5.20 \pm 0.31^{1) 22}$ & $4.20 \pm 0.26^{\mathrm{a}}$ & $3.40 \pm 0.33^{\mathrm{a}}$ & $3.60 \pm 0.36^{\mathrm{a}}$ & $3.70 \pm 0.33^{\mathrm{a}}$ \\
A & $5.40 \pm 0.23^{\mathrm{a}}$ & $4.30 \pm 0.30^{\mathrm{a}}$ & $3.70 \pm 0.29^{\mathrm{a}}$ & $4.25 \pm 0.42^{\mathrm{a}}$ & $4.10 \pm 0.29^{\mathrm{a}}$ \\
B & $4.80 \pm 0.34^{\mathrm{a}}$ & $4.90 \pm 0.22^{\mathrm{a}}$ & $3.35 \pm 0.31^{\mathrm{a}}$ & $3.50 \pm 0.37^{\mathrm{a}}$ & $3.55 \pm 0.27^{\mathrm{a}}$ \\
C & $4.40 \pm 0.39^{\mathrm{a}}$ & $4.60 \pm 0.24^{\mathrm{a}}$ & $3.50 \pm 0.25^{\mathrm{a}}$ & $3.60 \pm 0.39^{\mathrm{a}}$ & $3.65 \pm 0.28^{\mathrm{a}}$ \\
D & $5.60 \pm 0.26^{\mathrm{a}}$ & $4.65 \pm 0.31^{\mathrm{a}}$ & $3.90 \pm 0.30^{\mathrm{a}}$ & $4.20 \pm 0.37^{\mathrm{a}}$ & $4.35 \pm 0.25^{\mathrm{a}}$ \\
E & $5.10 \pm 0.29^{\mathrm{a}}$ & $4.50 \pm 0.26^{\mathrm{a}}$ & $3.60 \pm 0.28^{\mathrm{a}}$ & $3.60 \pm 0.37^{\mathrm{a}}$ & $3.90 \pm 0.25^{\mathrm{a}}$ \\
F & $5.35 \pm 0.24^{\mathrm{a}}$ & $4.30 \pm 0.29^{\mathrm{a}}$ & $3.65 \pm 0.20^{\mathrm{a}}$ & $3.55 \pm 0.37^{\mathrm{a}}$ & $4.00 \pm 0.19^{\mathrm{a}}$ \\
\hline
\end{tabular}

\footnotetext{
${ }^{1)}$ The values were expressed as mean $\pm \mathrm{SD}(\mathrm{n}=20)$.

${ }^{2)}$ Different letters within the same column indicate significant difference $(\mathrm{p}<0.05)$.
} 
발효한 Kwon 등(15)의 연구결과에서도 P. anomala JK04의 사용에 따라 다양한 ester 화합물이 생성되는 것을 확인하였 으며, Mingorance-Cazorla 등(32)은 12종의 서로 다른 효모 중 P. anomala OJ5로 포도주를 발효시켰을 때, ethyl acetate 와 high alcohol의 함량이 가장 좋은 비율을 가진다고 보고 하였다. 본 연구에서도 $P$. anomala JK04를 S. cerevisiae Fermivin과 함께 발효에 이용하였을 때, aldehyde와 acid의 함량이 대조구에 비하여 소폭 증가하였으나, 가장 중요한 향기성분인 각종 ester 화합물이 크게 증가하여 와인의 관능 적 품질을 향상시킨 것을 확인하였다. 블렌딩 와인의 관능 평가 결과를 Table 6에 나타내었다. 관능평가 결과, 모든 항목에서 유의적인 차이는 나타나지 않았으나, 블렌딩와인 의 색은 P. anomala JK04로 단독발효한 아로니아 와인을 첨가한 시험구(A, D)와 $S$. cerevisiae Fermivin으로만 발효를 진행한 시험구 $(\mathrm{F})$ 에서 대조구보다 높은 점수를 얻었다. 블 렌딩와인의 향기 항목에서는 모든 블렌딩와인이 대조구보 다 높은 점수를 얻었으며, 특히 혼합발효된 캠벨얼리 와인 과 아로니아 와인을 블렌딩 한 시험구(B)에서 가장 높은 점수를 얻었다. 블렌딩와인의 맛과 신맛 항목에서는 $P$. anomala JK04로 단독발효한 아로니아 와인을 첨가한 시험 구 $(\mathrm{A}, \mathrm{D})$ 에서 상대적으로 높은 점수를 받았다. 맛 항목의 경우, P. anomala JK04 단독발효에 의해 아로니아 와인에 남겨진 잔당의 영향인 것으로 보여지며, 신맛의 경우 발효 과정 중 와인의 신맛에 관여하는 malic acid의 함량이 높게 나타났기 때문으로 보여진다. 블렌딩와인의 종합적인 기호 도는 $S$. cerevisiae Fermivin으로 단독발효한 캠벨얼리 와인 과 $P$. anomala $\mathrm{JK} 04$ 로 단독발효한 아로니아 와인으로 블렌 딩한 시험구(D)가 가장 높은 점수를 받았고, 그 다음으로 혼합발효한 캠벨얼리 와인과 $P$. anomala $\mathrm{JK} 04$ 로 단독발효 한 아로니아 와인으로 블렌딩한 시험구(A)가 높은 점수를 받았다.

\section{요 약}

본 연구는 국산 캠벨얼리 와인의 주질 개선과 기능성 향상을 위해 캠벨얼리 뿐만 아니라 안토시아닌과 폴리페놀 성분이 풍부하여 항산화능이 우수하다고 알려진 아로니아 를 이용하여 상업용 효모인 S. cerevisiae Fermivin과 향미 증진능을 지닌 P. anomala JK04를 각각 단독 또는 5:5(v/v) 의 비율로 혼합발효한 후 블렌딩하는 실험을 진행하였다. 최적 블렌딩 비율을 정하기 위하여 예비실험으로 캠벨얼리 와인에 아로니아 와인을 각각 $5,10,20 \%(\mathrm{v} / \mathrm{v})$ 첨가하여 항산화능과 관능검사를 실시하였으며, 실험 결과를 바탕으 로 캠벨얼리 와인과 아로니아 와인의 블렌딩 비율을 9:1(v/v)로 설정하였다. P. anomala JK04로 단독발효한 캠 벨얼리 와인은 낮은 알코올 함량으로 인해 블렌딩에서 제외
하였고, 나머지는 발효에 이용된 균주에 따라 블렌딩하였 다.

블렌딩와인의 기능성을 평가하기 위하여 총 안토시아닌 함량, DPPH 라디칼 소거능, 총 페놀성 화합물 함량 분석을 진행하였으며, 모든 블렌딩와인에서 대조구인 S. cerevisiae 로 단독발효한 캠벨얼리보다 높은 수치를 나타내었다. 블 렌딩와인의 유리당 분석 결과에서는 P. anomala $\mathrm{JK} 04$ 로 단독발효한 아로니아 와인을 첨가한 시험구 $(\mathrm{A}, \mathrm{D})$ 에서 glucose와 fructose 같은 잔당이 남아있는 것을 확인하였으 며, 유기산 분석 결과에서는 상기 두 시험구에서 특히 malic acid 함량이 높게 측정되었다.

블렌딩와인의 외관적 품질을 검사하기 위해 색도, 휘발 성 향기성분, 관능검사가 수행되었으며, $P$. anomala JK04를 사용 여부에 따라 A, B, C와 D, E, F 순으로 hue와 intensity 값이 증가하는 경향을 나타내었다. 또한 Hunter's color value에서는 아로니아 와인의 첨가가 와인의 $\mathrm{a}$ value와 $\mathrm{b}$ value를 증가시키는 경향을 나타내었다. 휘발성 향기성분 분석에서는 P. anomala JK04의 사용이 와인에 부정적인 성분인 aldehyde와 acid 함량이 소폭 증가시키긴 하였지만, 중요한 향기성분은 ester 화합물의 함량이 큰 폭으로 증가하 는 것을 확인하였다. 관능검사 결과에서는 $P$. anomala $\mathrm{JK} 04$ 로 단독발효한 아로니아 와인을 사용한 시험구(A,D)에서 색, 맛, 신맛, 전반적인 기호도에서 다른 시험구보다 높은 점수를 받았으며, 향기 항목에서는 모든 블렌딩와인이 대 조구보다 높은 점수를 받았다.

본 연구에서는 캠벨얼리 와인에 아로니아 와인을 블렌딩 하여 기능성을 증가시켰으며, S. cerevisiae Fermivin과 $P$. anomala JK04를 혼합발효하여 향기성분의 증가 및 관능적 품질이 향상됨을 확인하였다.

\section{감사의 글}

본 연구는 2017년 농촌진흥청 어젠다 과제(PJ012425022017) 의 연구비 지원에 의해 수행되었으며 이에 감사드립니다.

\section{References}

1. Kim MA (2015) Fermentation characteristics of Campbell Early wine based on the amount of Korean indigenous Hanseniaspora uvarum cells. MS Thesis, Kyungpook National University, Korea, p 1

2. Yook C, Seo MH, Kim DH, Kim JS (2007) Quality improvement of Campbell Early wine by mixing with different fruits. Korean J Food Sci Technol, 39, 390-399

3. Kim SH, Choi IM, Cho JG, Han JH, Hwang JH, Seo 
HH, Yun HK (2011) Correlation analysis between fruit quality of 'Campbell Early' grapes and climatic factors. Korean J Agric For Meteorol, 13, 93-100

4. Lee JB (2014) Effects of a Hanseniaspora uvarum isolated from Korean grapes on the quality of wine fermented using Campbell Early grape must. MS Thesis, Kyungpook National University, Korea, p 2

5. Kim DH, Hong YA, Park HD (2008) Co-fermentation of grape must by Issatchenkia orientalis and Saccharomyces cerevisiae reduces the malic acid content in wine. Biotechnol Lett, 30, 1633-1638

6. Chang EH, Jeong ST, Jeong SM, Lim BS, Noh JH, Park KS, Park SJ, Choi JU (2011) Deacidification effect of Campbell Early must through carbonic-maceration treatment: Isolation and properties of the bacteria associated with deacidification. Korean J Food Preserv, 18, 973-979

7. Lee SB, Kim DH, Park HD (2016) Effects of protectant and rehydration conditions on the survival rate and malolactic fermentation efficiency of freeze-dried Lactobacillus plantarum JH287. Appl Microbiol Biotechnol, 100, 7853-7863

8. Hong YA, Park HD (2013) Role of non-Saccharomyces yeasts in Korean wines produced from Campbell Early grapes: Potential use of Hanseniaspora uvarum as a starter culture. Food Microbiol, 34, 207-214

9. Kahkonen MP, Hopia AI, Heinonen M (2001) Berry phenolics and their antioxidant activity. J Agric Food Chem, 49, 4076-4082

10. Hou DX (2003) Potential mechanisms of cancer chemoprevention by anthocyanins. Curr Mol Med, 3, 149-159

11. Park HJ, Chung HJ (2014) Influence of the addition of aronia powder on the quality and antioxidant activity of muffins. Korean J Food Preserv, 21, 668-675

12. Song JH (2016) Quality characteristics of yogurt dressing containing aronia (black chokeberry). MS Thesis, Sejong University, Korea, p 1-3

13. Park SH, Park JH, Noh JG, Shin HM, Lee SH, Kim YH, Eom HJ (2016) Quality characteristics and antioxidant activities of aronia jams added with apple. Korean J Food Preserv, 23, 180-187

14. Rojas V, Gil JV, Pinaga F, Manzanares P (2001) Studies on acetate ester production by non-Saccharomyces wine yeasts. Int J Food Microbiol, 70, 283-289

15. Kwon SJ, Choi JS, Yeo SH, Park HD (2015) Fermentation characteristics of persimmon wine by the mixed culture of Pichia anomala JK04 and Saccharomyces cerevisiae Fermivin cells. Korean J Food Preserv, 22, 768-777

16. Wahyono A, Lee SB, Kang WW, Park HD (2016) Improving bread quality using co-cultures of Saccharomyces cerevisiae, Torulaspora delbrueckii JK08, and Pichia anomala JK04. Ital J Food Sci, 28, 298-313

17. Kwon SJ (2015) Characteristics of persimmon wine fermented by the mixed culture of Pichia anomala JK04 and Saccharomyces cerevisiae Fermivin. MS Thesis, Kyungpook National University, Korea, p 18-27

18. AOAC (2000) Official method of analysis. $17^{\text {th }} \mathrm{Ed}$, Association of official analytical chemists, Washington DC, USA, p 210-219

19. Ahmed H (2004) Principles and reactions of protein extraction, purification and characterization. CRC Press, London, England, p 350-352

20. Liquors Licence Aid Center (2010) Code for analysis of alcoholic beverages. National Tax Service, Seoul, Korea, p 39, p 104-202

21. KFDA (2010) Food code. Korean Food \& Drug Administration, Seoul, Korea, 10, 3-25

22. Giusti MM, Wrolstad RE (2001) Characterization and measurement of anthocyanins by UV-visible spectroscopy. Curr Protoc Food Analyt Chem, F1.2.1-F1.2.13.

23. Ough CS, Amerine MA (1980) Methods for analysis of musts and wines. Wiley \& Sons, New York, NY, USA, p $176-180$

24. Yoo CY (2013) Antioxidant and anti-diabetes inhibitory activity of Gossypium semen extracts. MS Thesis, Kyungpook National University, Daegu, Korea, p 6

25. Kim DH, Lee SB, Park HD (2014) Fermentation characteristics of cider from late harvest Fuji apples by a sugar tolerant yeast, Saccharomyces cerevisiae SS89. Korean J Food Preserv, 21, 917-924

26. SAS (2004) SAS/STAT 9.3 user's guide. SAS Institute Inc, Cary, NC, USA, p 313-383

27. Domizio P, Romani C, Lencioni L, Comitini F, Gobbi M, Mannazzu I, Ciani M (2011) Outlining a future for non-Saccharomyces yeasts: Selection of putative spoilage wine strains to be used in association with Saccharomyces cerevisiae for grape juice fermentation. Int J Food Micriobiol, 147, 170-180

28. Park WM, Park HG, Rhee SJ, Lee CH, Yoon KE (2002) Suitability of domestic grape, cultivar Campbell's Early, for production of red wine. Korean J Food Sci Technol, 34, 590-596 
29. Jackson RS (2008) Wine science: Principles and applications. $3^{\text {th }}$ ed, Academic Press, New York, NY, USA, p 1-14

30. Lee JA, Yoon JY (2016) The quality and antioxidant properties of cookies containing aronia powder. Culi Sci Hos Res, 22, 179-189

31. Vas G, Gal L, Harangi J, Dobo A, Vekey K (1998) Determination of volatile aroma compounds of blaufrankisch wines extracted by solid-phase microextraction. J Chromtogr Sci, 36, 505-510

32. Mingorance-Cazorla L, Clemente-Jimenez JM, MartinezRodriguez S, Las Heras-Vazquez FJ, Rodriguez-Vico F (2003) Contribution of different natural yeasts to the aroma of two alcoholic beverages. World J Microbiol Biotechnol, 19, 297-304

33. Sun SY, Che CY, Sun TF, Lv ZZ, He SX, Gu HN, Shen WJ, Chi DC, Gao Y (2013) Evaluation of sequential inoculation of Saccharomyces cerevisiae and Oenococcus oeni strains on the chemical and aromatic profiles of cherry wines. Food Chem, 138, 2233 - 2241
34. Jeong EJ, Jeon SY, Baek JH, Cha YJ (2011) Volatile flavor compounds in commercial vinegar beverages derived from fruits. J Life Sci, 21, 292-299

35. Molina AM, Swiegers JH, Varela C, Pretorius IS, Agosin E (2007) Influence of wine fermentation temperature on the synthesis of yeast-derived volatile aroma compounds. Appl Microbiol Biotechnol, 77, 675-687

36. Jiang B, Zhang Z (2010) Volatile compounds of young wines from Cabernet Sauvignon, Cabernet Gernischet and Chardonnay varieties grown in the Loess Plateau region of China. Molecules, 15, 9184-9196

37. Duarte WF, Dias DR, Oliveira JM, Vilanova M, Teixeira JA, Almeida e Silvar JB, Schwan RF (2010) Raspberry (Rubus idaeus L.) wine: Yeast selection, sensory evaluation and instrumental analysis of volatile and other compounds. Food Res Int, 43, 2303-2314

38. Dixon J, Hewett EW (2000) Factors affecting apple aroma/flavour volatile concentration: A Review. New Zeal J Crop Hortic Sci, 28, 155-173 